\title{
Ability of indigenous Bacillus licheniformis and Bacillus subtilis in microbial enhanced oil recovery
}

\author{
${ }^{I}$ S. Haghighat; ${ }^{1}$ A. Akhavan Sepahy $;{ }^{2}{ }^{*}$ M. Mazaheri Assadi; ${ }^{3}$ H. Pasdar \\ ${ }^{I}$ Department of Microbiology, Islamic Azad University, North Tehran Branch, Tehran, Iran \\ ${ }^{2}$ Environmental Biotechnology Group, Department of Biotechnology, Iranian Research Organization for Science \\ and Technology, Tehran, Iran \\ ${ }^{3}$ Department of Chemistry, Islamic Azad University, North Tehran Branch, Tehran, Iran
}

Received 2 January 2008; revised 8 February 2008; accepted 28 February 2008

\begin{abstract}
ABSTARCT: Microbially produced lipopeptide have been isolated and studied for microbial enhanced oil recovery. About 60 gram positive bacteria isolated from soil contaminated with crude oil, near the crude oil storage tank in Tehran Refinery, Tehran, Iran. However, most of these studies have produced lipopeptide by one of the pure-culture microbes isolated in a laboratory. Among the isolates, heamolytic tests revealed two biosurfactant producers. The isolated strains were designated as C2, E1. By using morphological, biochemical and molecular biology tests (16 SrRNA), the strains identified as Bacillus licheniformis and Bacillus subtitlis, respectively. Emulsification activity and measurement of surface tension indicated that, the isolates were high producers of biosurfactant. The product of C2 and E1 is mainly lipopeptide. This product reduce surface tension from 65 to $30 \mathrm{mN} / \mathrm{m}$. Emulsified activity of crude oil was $92 \%$ for C2 and $90 \%$ in case of E1. This is the first report of indigenous Bacillus licheniformis and Bacillus subtilis from a soil contaminated with oil in an Iranian refinery with ability to produce biosurfactant.
\end{abstract}

Key words: Surface tension, emulsification activity, lipopeptide, crude oil, Bacilli

\section{INTRODUCTION}

Microbial enhanced oil recovery (MEOR) is an important tertiary recovery technology utilizing microorganisms and/or their metabolic products for recovery of residual oil. It is generally accepted that approximately $30 \%$ of the oil present in a reservoir can be recovered using current enhanced oil recovery (EOR) technology (Abtani and Reestaazad, 2001; Khire and Khan, 1994; Premuzic, 1992). However, techniques involving the use of chemical or physical processes such as pressurization, water flooding of steaming is generally inapplicable to most oil reservoirs (Vanbyke, 1991). The use of chemical surfactants for cleaning up oil reservoirs in an unfavorable practice that is hazardous and costly and will leave undesirable residues which are difficult to dispose without adversely affecting the environment (Turkovskaya, 1999). Poor oil recovery in existing producing wells may be due to several factors. The main factor is the low permeability of some reservoirs or the high viscosity of the oil which results in poor

$\triangle$ *Corresponding Author Email: mxmazaheriassadi@yahoo.com Tel.: +982188838350 mobility. High interfacial tensions between the water and oil may also result in high capillary forces retaining the oil in the reservoir rock (Banat, 1995a). Biosurfactants are a diverse group of surface active chemical compounds that are produced by a wide variety of microorganisms such as Bacillus sp. (Cooper and Goldenbergy, 1999; Sung and Kuo, 1998). Having both polar and non-polar domains, biosurfactants are able to partition at the water/air or water/oil interfaces and thus lower the interfacial of surface tension (Youssef et al., 2004). Such properties make them good candidates for EOR (Bannat, 1995b; Bannat et al., 2000). This biological surface active compounds have several advantages over the chemical surfactant such as lower toxicity, higher degradability and better environmental compatability, higher foaming, higher selectivity and specific activity at extreme $\mathrm{pH}$, temperature and salinity (Fietcher, 1992; Sullivan, 1998; Gautham and Taygi, 2006; Bodour and Miller, 2002; Gerson, 1998). In the present studies, isolation and identification of lipopeptide producing bacilli and extraction of biosurfactant were assessed. 
The bio-products excreted by these strains cause a series of very desirable changes in the properties of the crude oil (Mahmudieh Lab, 2007).

\section{MATERIALS AND METHODS}

Soil samples were obtained from contaminated area close to the storage and distribution center of oil products in Tehran refinery. All samples were collected in triplicates. Processing on soil samples began immediately upon arrival in the laboratory. $1 \mathrm{~mL}$ of each soil sample was added to $9 \mathrm{ml}$ of $0.9 \%$ sodium chloride solution. The mixture was placed on a reciprocal shaker for $1 \mathrm{~h}$. to produce a well dispersed suspension (Francy and Thomas, 1991; Adria et al., 2003). By inoculating sheep blood agar, heamolytic test was performed (Banat, 1995). Lipopeptides are metabolites which are capable to destroy the membrane of erythrocytes. Surface tension was determined using a DU-NOUY test (Akhavan Sepahy et al., 2005). Bacillus Sp. was isolated by pour plate technique on plate count agar. Individual culture was preliminary identified by morphological, biochemical and molecular biology techniques. Using the taxonomic scheme of Bergey's manual of determinative bacteriology and 16S rRNA using $\mathrm{fD}_{1}$ and $\mathrm{rD}_{1}$ primers. $16 \mathrm{~S}$ rRNA method has several steps as below:

- DNA extraction by Amersham kits

- electrophoresis in agarose gel

- PCR with special primers that contains nucleotides as below:

\section{$\mathrm{fD}_{1}$ 5'-AGAGTTTGATCCTGGCTCAG-3'}

$\mathrm{rD}_{1}$ 5'-AAGGAGGTGATCCAGCC -3'

Samples had been sent to SQ lab Co. (Germany) for further molecular biology studies. By receiving the result, other strain was compared and matched strains were detected. The graphs had been drawn by special software recognized as the unknown nucleotides. Eventually, the results were compared with gene bank sequences (Blackwood and Turenne, 2004). Nutrient broth (Merck) was used for preparation of the inoculums. The cultures were grown in this broth for $8-12$ at $35{ }^{\circ} \mathrm{C}\left(\mathrm{OD}_{450} \mathrm{~nm}\right.$ 0.8-0.9). For biosurfactant synthesis a mineral salts medium (MSM) with the following composition was used: $\mathrm{Na}_{2} \mathrm{HPO}_{4} 2 \mathrm{~g} / \mathrm{L}$, $\mathrm{KH}_{2} \mathrm{PO}_{4} 2 \mathrm{~g} / \mathrm{L}, \mathrm{MgSO}_{4} .7 \mathrm{H}_{2} \mathrm{O} 0 / 01 \mathrm{~g} / \mathrm{L}, \mathrm{NaNO}_{3} 2.5 \mathrm{~g} / \mathrm{L}$, $\mathrm{NaCl} 0.8 \mathrm{~g} / \mathrm{L}, \mathrm{CaCl}_{2} 0 / 2 \mathrm{~g} / \mathrm{L}, \mathrm{KCl}$ 0/8 $\mathrm{g} / \mathrm{L}, \mathrm{FeSO}_{4} .7 \mathrm{H}_{2} \mathrm{O}$ 0/ $001 \mathrm{~g} / \mathrm{L}$ and $1 \mathrm{~mL}$ of trace element solution containing $(\mathrm{mg} / \mathrm{L}) \mathrm{ZnSO}_{4} \cdot 7 \mathrm{H}_{2} \mathrm{O} 525 \mathrm{mg} / \mathrm{L}, \mathrm{MnSO}_{4} \cdot 4 \mathrm{H}_{2} \mathrm{O} 200$ $\mathrm{mg} / \mathrm{L}, \mathrm{CuSO}_{4} \cdot 5 \mathrm{H}_{2} \mathrm{O} 705 \mathrm{mg} / \mathrm{L}, \mathrm{Na}_{2} \mathrm{MnO}_{4} \cdot 2 \mathrm{H}_{2} \mathrm{O} 15 \mathrm{mg} /$
$\mathrm{L}, \mathrm{COCl}_{2} .6 \mathrm{H}_{2} \mathrm{O} 200 \mathrm{mg} / \mathrm{L}, \mathrm{H}_{3}-\mathrm{BO}_{3} 15 \mathrm{mg} / \mathrm{L}, \mathrm{NiSO}_{4} .6$ $\mathrm{H}_{2} \mathrm{O} 27 \mathrm{mg} / \mathrm{L}$ (Francy and Thomas, 1991). The carbohydrate (glucose, sucrose, fructose and mannose) were added to a final concentration of $2 \%(\mathrm{~V} / \mathrm{V})$. The hydrocarbon substrates (crude oil) were added separately at $2 \%(\mathrm{~V} / \mathrm{V})$ concentration. Different nitrogen sources such as sodium nitrate, peptone and yeast extract were added (3\%) to the culture medium. Growth studies were done in flasks containing $200 \mathrm{~mL}$ medium at $30-50{ }^{\circ} \mathrm{C}$ with shaking at $200 \mathrm{rpm}$. Biosurfactant production at different $\mathrm{NaCl}$ concentration, $\mathrm{pH}$, the $\mathrm{NaCl}$ was determined. $\mathrm{pH}$ of the medium were adjusted accordingly. Experiments were done in duplicate and the results reported are averages of there independent experiments (Tulra et al., 2002). Emulsification activity was measured using the method described by Cooper and Goldenbergy (1999) and Tabatabaee et al. (2005). The method used for lipopeptide extraction was modified from the previous work of Youssef et al. (2004). In a liter flask, $200 \mathrm{~mL}$ culture was grown in medium (MSM) with $2 \%$ crude oil. After about $48 \mathrm{~h}$., aliquot were checked for biosurfactant production by using the surface tension test. Cells were then removed by centrifugation at $10.000 \mathrm{rpm}$ for $15 \mathrm{~min}$. at $4{ }^{\circ} \mathrm{C}$. The culture broth were acidified to $\mathrm{pH} 2.0$ by $1 \% \mathrm{HCl}$ and extracted with ethyl ether $(1: 2 \mathrm{~V} / \mathrm{V})$. The ether phase was evaporated under vacuum at $35^{\circ} \mathrm{C}$. The residual lipid extract was then redisolved in dichloromethane and fractionated on a activated silica-gel 60 plates $(20 \times 20 \times 0 / 25 \mathrm{~cm}$, MERK, F.R.G) using chloroform-methanol-acetic acidwater mixture (25:15:4:2) as a solvent system. The lipid components were detected as brown spots on the plates after spraying with potassium dichromate in sulfuric acid and heating at $150^{\circ} \mathrm{C}$ for $15 \mathrm{~min}$. Aminoacid components were detected as red spots after the plates were sprayed with nine hydrine solution and heated for $10 \mathrm{~min}$ at $110^{\circ} \mathrm{C}$. These components were identified by comparison with published reports and against known standards (Abu Ruwaida and Banat, 1991; Tulra et al., 2002; Kim et al., 2000).

\section{RESULTS AND DISCUSSION}

The production of surface active compounds or lipopeptide by microorganisms has been a subject of increasing interest in recent years, especially due to their potential applications in enhanced oil recovery. Because of the diversity of microorganisms in such a environment and the heterogeneity of many 
environments at a microbial level, a large number of different methods have been developed to detect and/ or identify as large a proportion of the microorganisms present as possible. Anyhow, due to the diversity of microorganisms and the different niches in which they inhabit and no single method is applicable for the extraction, detection or identification of all the microorganisms in soil contaminated with oil sample. Hence, this study tried with specific medium for bacilli species. About 60 strains of Bacillus isolated from contaminated area close to the storage and distribution center of oil products in Tehran refinery. These strains were selected for further studies. Since hemolytic activity is one of the tools to characterize bacteria, hemolytic activity of bacterial strains was determined by inoculating sheep blood agar. Lipopeptides are also metabolites which are capable to destroy the membrane of erythrocytes. Depicted results in Fig. 1 is enough evidence for both the strains ability to produce biosurfactant. The isolated strains were identified by morphological, biochemical and molecular biology technique using the taxonomic scheme of Bergy's manual of determinative bacteriology and 16 SrRNA gene. PCR products were first obtained using Taq DNA polymerase and genomic DNA as a template and $\mathrm{f} D_{1}$ and $\mathrm{r} D_{1}$ as primers following $10 \mathrm{~min}$. of initial denaturation at $94{ }^{\circ} \mathrm{C} ; 30$ cycles of $45 \mathrm{~s}$ at $94^{\circ} \mathrm{C}, 45 \mathrm{~s}$ at $56^{\circ} \mathrm{C}$ and $60 \mathrm{~s}$ at $72{ }^{\circ} \mathrm{C}$ and a final elongation step of $10 \mathrm{~min}$. at $72^{\circ} \mathrm{C}$. Products were visualized with ethidium bromide after running on a $1 \%$ agarose gel. DNA was extracted from the gels. PCR products were diluted 1:50 and used as a template for incorporation under the same PCR conditions, using DIG PCR labeling mixture (Roche). the obtained results of 16 SrRNA, determined with special software comparison of the sequence with the sequences available in the database revealed $99 \%$ identity with Bacillus licheniformis and Bacillus subtilis. A standard emulsion assay was used to determine the emulsifying activities of pure isolated bacilli strains. Units of emulsifying activity are defined in Materials and Methods. The specific emulsifying activities of the Bacillus licheniformis were $92 \%$ and Bacillus subtilis $90 \%$, respectively. However, identified species had a capability to reduce surface tension in their culture broth to values 30 and $29 \mathrm{mN} / \mathrm{m}$. Some effective biosurfactants are able to reduce the surface tension of water from $65 \mathrm{mN} / \mathrm{m}$ to $29 \mathrm{mN} / \mathrm{m}$. The obtained results are comparable with the results
Fig. 1: Heamolaysis test on blood agar

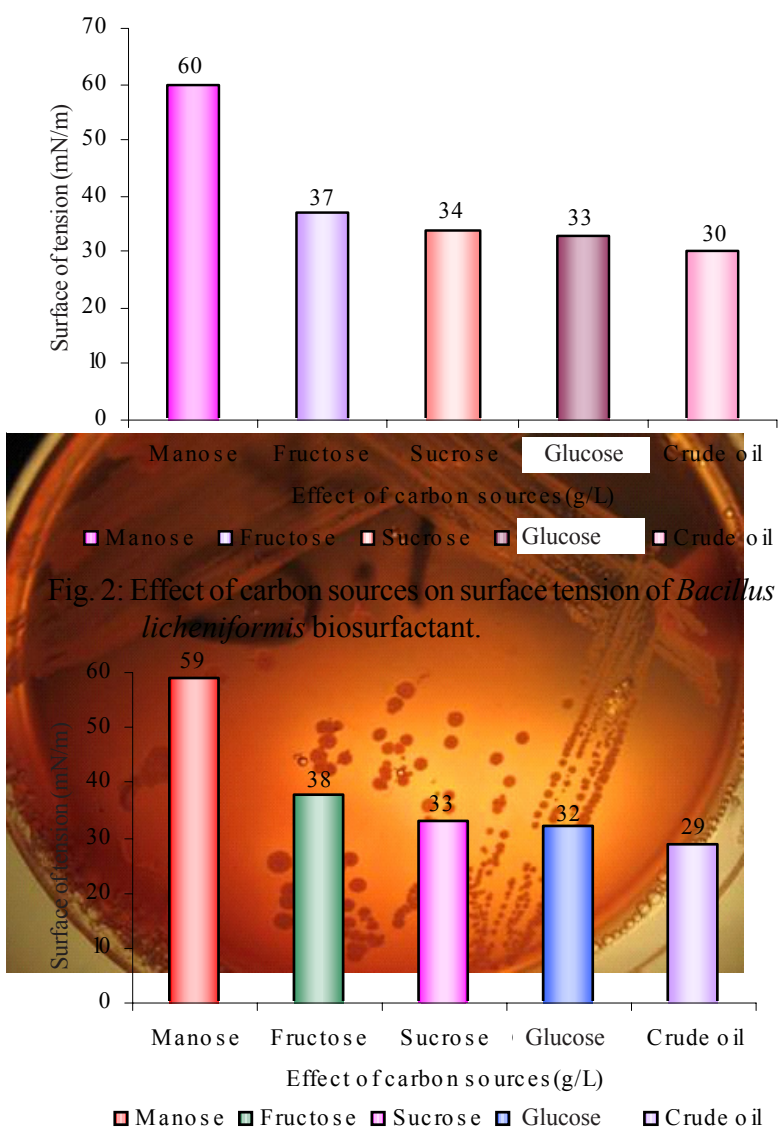

Fig. 3: Effect of carbon sources on surface tension of Bacillus subtilis biosurfactant

obtained by Banat (1995a). The ability of these strains to grow on crude oil, glucose, sucrose, manose, lactose as carbon sources is shown in Figs. 2 and 3. the depicted results revealed that (in Figs. 2 and 3) crude oil was the best source of carbon and energy for biosurfactant 


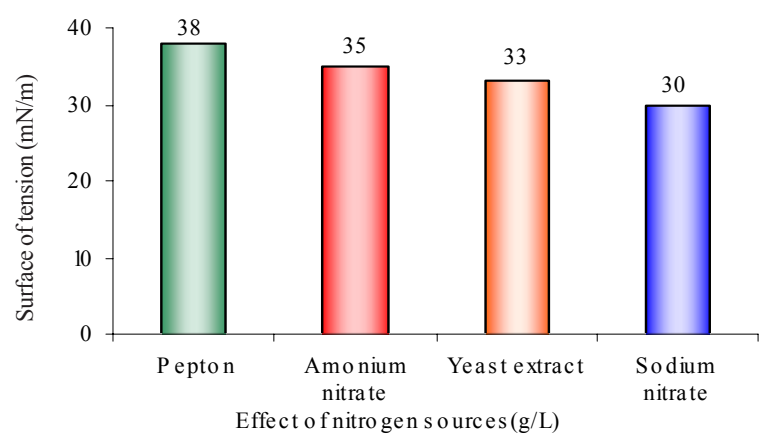

$\square$ Pepton $\boldsymbol{\square}$ Amonium nitrate $\boldsymbol{\square}$ Yeas textract $\boldsymbol{\square}$ Sodium nitrate

Fig. 4: Effect of nitrogen sources on surface tension of Bacillus licheniformis on production lipopeptide

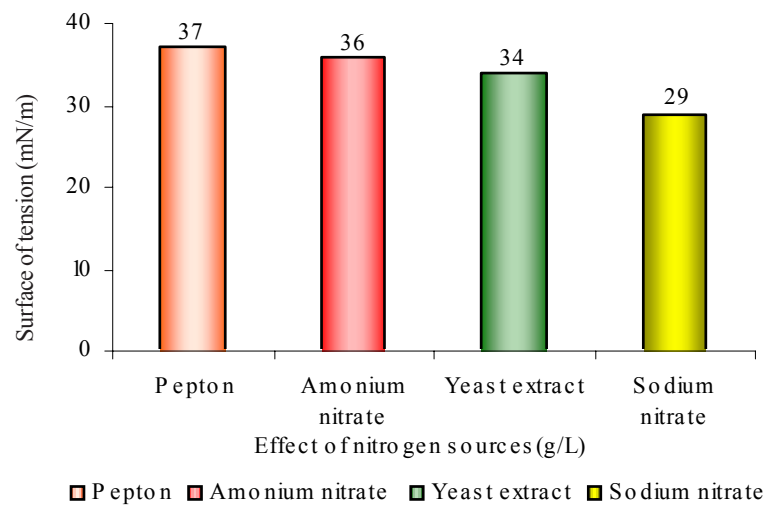

Fig. 5: Effect of nitrogen sources on surface tension of Bacillus subtilis lipopeptide

production by the isolated bacteria. In present study, the conditions were standardized for the maximum lipopeptide production by Bacillus licheniformis and Bacillus subtilis at mesophilic growth conditions. The results of variation in nitrogen sources such as Yeast extract, ammonium nitrate, peptone and sodium nitrate are shown in Figs. 4 and 5. The effects of these nitrogen sources on surface tension by Bacillus licheniformis and Bacillus subtilis showed $35 \mathrm{mN} / \mathrm{m}$ and $36 \mathrm{mN} / \mathrm{m}$ reduction, respetively. The depicted results in Figs. 4 and 5 showed that sodium nitrate is applicable for lipopeptide production using locally isolated strains. A number of studies have indicated that the type of medium and growth conditions can influence the type and yield of biosurfactant. In this regard, this study examines the effect of carbon, nitrogen sources, $\mathrm{pH}$ and $\mathrm{NaCl}$ concentrations. The isolated Bacillus strains in this investigation were able to utilize different carbon sources in order to produce lipopeptide in mesophilic condition. Although there are reports on biosurfactant production in mesophilic condition, but Makkar and

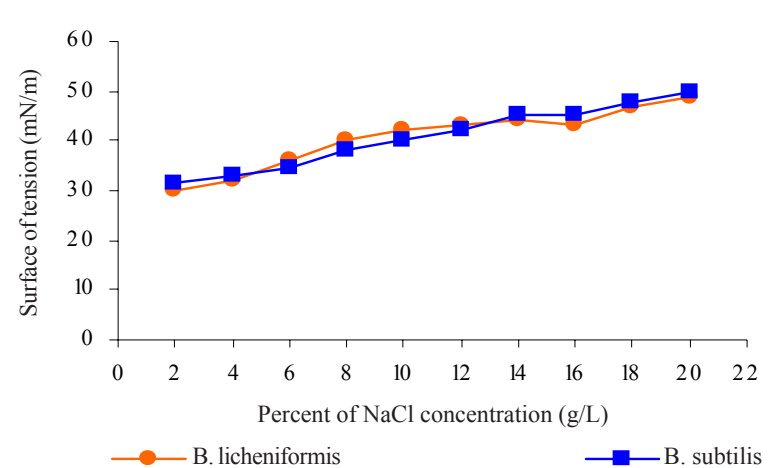

Fig. 6: Effect of $\mathrm{NaCl}$ concentration on surface tension using Bacillus licheniformis and Bacillus subtilis

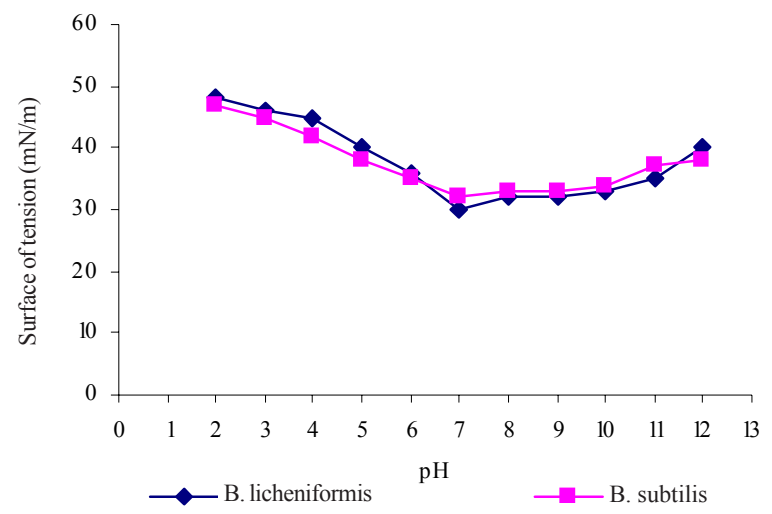

Fig. 7: Effect of $\mathrm{pH}$ on surface tension of Bacillus licheniformis and Bacillus subtilis

Cameotra (1998) isolated a thermophilic Bacillus strain on a hydrocarbon containing medium. Biosynthesis of lipopetide was reduced when above $6 \% \mathrm{NaCl}$ were used. Different $\mathrm{NaCl}$ concentrations (2-20\%) had effects on lipopeptide biosynthesis. As it is shown in Fig. 6, sodium chloride addition to the medium affected reduction of surface tension. Higher $\mathrm{NaCl}$ concentration in the medium did not affect the ability of the isolated bacteria in the reduction of surface tension considerably. The isolated strains behaved like the studies of Yakimov and Amro (1997). They reported that isolation of strain of Bacillus licheniformis from a petroleum reservoir was able to produce surfactant oprimally at $6 \% \mathrm{NaCl}$ concentration (Banat, 1993). Fig. 7 shows the effect of $\mathrm{pH}$ on the surface tension of Bacillus licheniformis and Bacillus subtilis biosurfactant, respectively. These strains were grown at $\mathrm{pH}$ values between 6 to 9 but the optimum $\mathrm{pH}$ for both the indigenous bacilli were 6.8 . When these strains were grown at $\mathrm{pH}$ values of 4 , there is no considerable lipopeptide production. Preliminary the analysis of the biosurfactant produced 
Table 1: Experimental $\mathrm{Rf}$ data for surface active lipid components isolated from Bacillus licheniformis culture

\begin{tabular}{lll}
\hline Extract fraction & Rf & Presumed component \\
\hline A & $0.06-0.12$ & Monoglyceride \\
B & $0.20-0.24$ & Diglyceride \\
C & $0.50-0.60$ & Neutral lipids \\
D & 0.8 & Amino-acid \\
\hline
\end{tabular}

Table 2: Experimental Rf data for surface-active lipid components isolated from Bacillus subtilis culture

\begin{tabular}{lll}
\hline Extract fraction & Rf & Presumed component \\
\hline A & $0.05-0.14$ & Monoglyceride \\
B & $0.20-0.26$ & Diglyceride \\
C & $0.40-0.80$ & Neutral lipids \\
D & 0.9 & Amino-acid \\
\hline
\end{tabular}

by Bacillus subtilis and Bacillus licheniformis culture indicated that the presence of different lipid compounds can be identified on the basis of their Rfvalues (Tables 1 and 2) as monoglycerides, diglycerides and natural lipids. A potassium dichromate in sulfuric acid fraction was also detected, indicating that the lipid extract contains a peptide substance. The present findings are similar to those reported in the literature for surface active lipids isolated from Bacillus licheniformis BA550 and Bacillus licheniformis jf-2 (Mc Inerney, Javaheri, 1990; Yakimov and Timmis, 1995; Jenny, 1992; Youssef et al., 2004). The potential of these strains to produce biosurfactant and their use in the oil industries, especially for MEOR, is apparent.

\section{REFERENCES}

Abtani, N.; Reestaazad, R., (2001). Microbial Enhanced oil Recovery(MEOR), The $11^{\text {th. }}$ oil, Gas and petrochemical congerss, Tehran.

Abu Ruwaida, A. S.; Banat, I. M., (1991). Isolation of biosurfactant producing bacteria product charaterization and evalution. Acta biotechnol., 11 (4), 315 - 324.

Adria, A.; Bodour, K.; Drees, P.; Raina, M. M., (2003). Distribution of biosurfactant-producing bacteria in undisturbed and contaminated Arid South Western soils. Appl. Environ. Microbiol, 69 (6), 3280-87

Akhavan Sepahy, A.; Mazaheri Assadi, M.; Noohi, A.; Sadjadian, V., (2005). Production of biosurfactant from Inranian oil fileds by isolated Bacilli, Int. J. Envi. Sci. Tech., 1(4), 287-293.

Banat, I. M., (1993). The isolation of a thermophilic biosurfactant producing Bacillus sp.Biotechno. Lett., 15 (5), 591-594.

Banat, I. M., (1995a). Biosurfactants production and possible uses in microbial enhanced oil recovery and oil pollution remediation., Biores. Tech., 51 (1), 1-12.
Banat, I. M., (1995b). Characterization of biosurfactants and their use in pollution removal - state of the art., Acta Biotech., 15 (3), 251-267.

Banat, I. M.; Makkar, R. S.; Cameotra, S., (2000). Potential commercial applications of microbial surfactants. Appl. Microb. Biotech., 5 (5), 495-508.

Bodour, A. A.; Miller Maier, R. M., (2002). Biosurfactants: types, screening methods, and applications, Encyclo. of Envi. Microbiol. Wiley \& Sons, N. Y. 750-770.

Blackwood, K. S.; Turenne, C. Y., (2004). Reassessment of sequence- Based Targets for Identification of Bacillus species, J. of Clinic. Microbiol., 42 (4), 1626-1630.

Cooper, D. G.; Goldenbergy, V. A., (1999). Surface active agents from two Bacillus species., App. and Envi. Microbiol., 189 (2), 224-229.

Fiechter, A., (1992). Biosurfactants: moving towards industrial application. Trends Biotech., 10 (6), 208-217.

Francy, D. S.; Thomas V., (1991). Emulsification of hydrocarbons by subsurface bacteria. J. Ind. Microbiol., 8 (4), 237-46.

Gautham, B.; Taygi, H., (2006). Microbial surfactants: A review, J. Oleo. Sci., 55, 155-166.

Gerson, D. F., (1998). Biosurfactants production properties applications surfactant. Science Series, 48, 269-280.

Jenny, K., (1991). Biosurfactants from Bacillus licheniformis: structural analysis and characterization. Appl. Microbiol. Biotech., 36 (1), 5-13.

Khire, J. M.; Khan, M. T., (1994). Microbially enhanced oil recovery (MEOR), Importance and mechanism of MEOR, Enz. Microbiol. Tech., 16, 170-172.

Kim, S. H.; Lim, E. J.; Lee S. O.; Leem, J. D; Lee, T. H., (2000). Purification and characterization of biosurfactant from Nocardia sp. L-417. Biotech. Appl. Biochem, 31, 249-253.

Makkar, R. S.; Cameotra, S. S., (1998). production of biosurfactant at mesophilic and thermophilic condition by a strain of Bacillus subtills, J. Ind. Microbiol., 20 (1), 4852.

Mc Inerney, M. J.; Javaheri, M., (1990). Properties of the biosurfactant produced by Bacillus licheniformis strain JF2. J. Indust. Microbiol., 5 (2-3), 95-102.

Premuzic Eugene, T., (1992). Microbial enhanced of oil recovery - recent advances, producing of the International conference on Microbial Enhanced Oil Recovery, Elsevier.

Sullivan, E. R., (1998). Molecular genetic of biosurfactant production, Cur. Opinion in Biotech., 9 (3), 263-264.

Sung, C. L.; L., Kuo, G., (1998). Enhanced biosurfactan production by a Bacillus licheniformis mutant. Enz. Microbiol. Tech., 23 (3-4), 267-273.

Tabatabaee, M.; Mazaheri Assadi, M.; Noohi A. A.; Sajadian, V. A., (2005). Isolation of Biosurfactant Producing Bacteria from Oil Reservoirs, Iranian J. Environ. Health Sci. Eng., $2(1), 6-12$,

Tulra, B.; Gorge, C.; Ivanov, R., (2002). Biosurfactant production by a new Pseudomonas putida strain. Z. Naturfersch, 57 (3-4), 356-360.

Turkovskaya, O. V., (1999). Surfactant and minal oil degrading microbial consortia. Resources, Cons. Recycl., 27, 178199.

Vanbyke, M., (1991). Application of microbial surfactants. Biotech. Adv., 9 (3), 241-252. 
Yakimov, M. M.; Amro, M., (1997). The potential of Bacillus licheniformis strains for in situ enhanced oil recovery. J. Petrol. Sci. Eng., 18 (1), 147-160.

Yakimov, M. M.; Timmis N. K., (1995). Characterization of a new lipopeptide surfactant produced by thermoolerant and halotolerant subsurface Bacillus licheniformis BAS50, Appl. Environ. Microbiol., 61(5),1706-1713.

Youssef, N.; Duncan, K. E.; Nagle, D.; Savage, K. N., (2004). Comparison of methods to detect biosurfactant production by diverse micro organisms. J. Microbiol, Meth., 56, 339-347.

\section{AUTHOR (S) BIOSKETCHES}

Haghighat S., M.Sc. student in the Department of Microbiology, Islamic Azad University, North Tehran Branch, Tehran, Iran. Email: setareh_haghighat@yahoo.com

Akhavan Sepahy, A., Ph.D., Department of Microbiology, Islamic Azad University, North Tehran Branch, Tehran, Iran. Email: akhavansepahy@gmail.com

Mazaheri Assadi, M., Ph.D., Environmental Biotechnology Group, Department of Biotechnology, Iranian Research Organization for Science and Technology, Tehran, Iran. Email: mxmazaheriassadi@yahoo.com

Pasdar, H., Ph.D., Department of Chemistry, Islamic Azad University, North Tehran Branch, Tehran, Iran. Email:hodapass@yahoo.com

\section{This article should be referenced as follows:}

Haghighat S.; Akhavan Sepahy, A.; Mazaheri Assadi, M.; Pasdar, H., (2008). Ability of indigenous Bacillus licheniformis and Bacillus subtilis in microbial enhanced oil recovery. Int. J. Environ. Sci. Tech., 5 (3), 385-390. 